\title{
Ecological implications of cheliped size in crabs: some data from Carcinus maenas and Liocarcinus holsatus
}

\author{
S. Y. Lee*, R. Seed \\ School of Ocean Sciences, University of Wales Bangor, Menai Bridge, Gwynedd LL59 5EY, UK
}

\begin{abstract}
Past studies on the size and structure of the chelipeds of predatory crabs have focused mainly on their use in foraging. This study of the morphometrics of the chelipeds of 2 predatory portunid crabs, Carcinus maenas L. and Liocarcinus holsatus (Fabricius) and the use of these structures in feeding, reproduction and agonistic interactions, provides further support to the view that the evolution of crab chelae is not driven by feeding requirements alone. Although individuals with larger chelipeds can feed on a wider range of prey species and sizes, the proportion of hard-bodied prey in the natural diet of $C$. maenas was small. Bigger chelae, however, confer selective advantages by increasing success in mate competition and intraspecific agonistic interactions. Field collections of mating pairs of C. maenas indicated that $>90 \%$ of mating males had chelae that were above the average size for the male population as a whole. Agonistic encounter experiments, in which crab models (constructed from empty moults) with chelae that were either larger than or smaller than the mean population values were presented to conspecifics suggested that cheliped size and meral spread was probably more important than overall body size in determining the response pattern of the subjects. Maintenance costs for chelipeds in $L$. holsatus estimated by respirometry were not significantly different from other body tissues as oxygen uptake rate could be predicted solely from dry tissue weight. Moreover, the rate of oxygen uptake was independent of the proportion of the total body weight that could be attributed to the chelipeds.
\end{abstract}

\section{INTRODUCTION}

The cheliped is a conspicuous structure of the brachyuran body. In crabs and other decapods such as lobsters the cheliped often comprises a high percentage of total body weight (Stein 1976) or a high size ratio with respect to overall body dimensions (Vermeij 1977). This has led to extensive studies on chelal biomechanics, morphology and anatomy (Hamilton et al. 1976, Warner \& Jones 1976, Brown et al. 1979, Elner \& Campbell 1981, Warner et al. 1982, Seed 1990a). Brachyuran chelae can often generate strong crushing forces (e.g. Warner \& Jones 1976, Brown et al. 1979, Elner \& Campbell 1981, Blundon \& Kennedy 1982), which, when applied through the occlusive surfaces, allows predatory species to feed on hard-shelled prey.

\footnotetext{
- Present address: The Swire Marine Laboratory, University of Hong Kong, Cape d'Aguilar, Shek O, Hong Kong
}

This aspect of cheliped ecology has focused mainly on crushing behaviour, optimality of the crushing process and impact on prey populations (Ebling et al. 1964 , Zipser \& Vermeij 1978, Elner 1980, Seed 1982, Jubb et al. 1983, Cunningham \& Hughes 1984, Jensen \& Jensen 1985, ap Rheinallt 1986, Davidson 1986 , Rangeley \& Thomas 1987, Sanchez-Salazar et al. 1987. Hughes 1989, Seed 1990b).

Hypotheses concerning the coevolution of cheliped size with hard-bodied prey in different zoogeographical regions have also been discussed (Vermeij 1976, 1977, Zipser \& Vermeij 1978, Abele et al. 1981). Elner (1978) considered that in heterochelous crabs the size of the larger (= master) chela serves as a template in determining prey preferences, thereby reflecting the strong emphasis placed on foraging needs as a selective force in cheliped evolution. Lawton \& Elner (1985) further proposed a reclassification of the genus Cancer based on chelal mechanics and morphology. 
While the importance of cheliped size, structure and strength in foraging is indisputable, other selective forces which may have contributed to the evolution of massive decapod chelipeds such as defence, intra- and interspecific interactions and reproduction are generally less well documented. If chelipeds are important in these functions which will influence individual fitness, their evolution must presumably have involved selective forces other than foraging needs. The present study attempts to evaluate the importance of various forces shaping the evolution of the brachyuran cheliped by investigating the implications of cheliped size in foraging, reproduction and agonistic encounters in 2 common portunid crabs, Carcinus maenas (L.) and Liocarcinus holsatus (Fabricius).

\section{MATERIALS AND METHODS}

Cheliped morphometrics. Samples of Carcinus maenas and Liocarcinus holsatus were collected either by trapping or trawling in shallow waters $(<20 \mathrm{~m})$ around the Menai Strait in North Wales during February and March 1989. Maximum carapace width, chelal height, position of the master chela (handedness) and mechanical advantage or grip strength (Alexander 1983) of both chelipeds were recorded for each crab (Fig. 1). The ratio of the fresh weight of the chelipeds to total body fresh weight was also recorded for subsamples ( $\mathrm{n}=106$ for $C$. maenas, $\mathrm{n}=25$ for $L$. holsatus) of crabs. Handedness data were collected for individuals of all size ranges ( $\mathrm{n}=412$ for $C$. maenas, $\mathrm{n}=112$ for $L$. holsatus). As chelal height and mechanical advantage change with size (Abby-Kalio \& Warner 1989), average values reported for these parameters were measured only from crabs of $>50 \mathrm{~mm}$ (range: 50.4 to $71.6 \mathrm{~mm}$ ) carapace width (CW) for C. maenas $(\mathrm{n}=206)$ and $>25 \mathrm{~mm}$ CW (range:

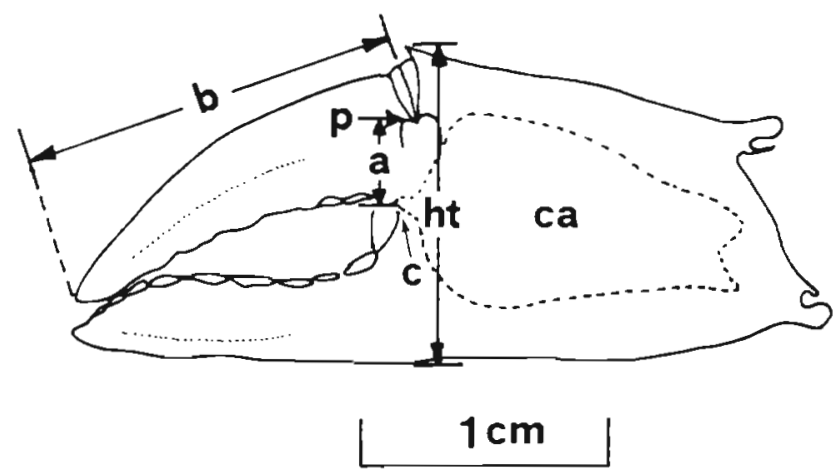

Fig. 1 Carcinus maenas. Diagram of a chela showing the various morphometric features measured. ht: chelal height;

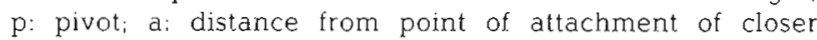
apodeme (c) to pivot; b: distance from pivot to tip of dactylus Mechanical advantage (MA) at dactylus tip $=a / b$
26.2 to $41.1 \mathrm{~mm}$ ) for $L$. holsatus ( $\mathrm{n}=81$ ). Crabs in these size ranges are all sexually mature individuals.

Prey handling. The importance of the chelipeds in foraging was examined by comparing the crushing efficiency of Carcinus maenas with chelae of different sizes using the mussel Mytilus edulis L. as prey. Two sets of experiments were conducted and only intact, male crabs in the intermoult stage were used. Hunger levels were standardized by starving the crabs for $24 \mathrm{~h}$ before the experiments. In the first set, individual crabs $(n=16, \mathrm{CW}$ range: 43.5 to $68.8 \mathrm{~mm}$ ) were offered mussels of various sizes and the time taken to break open the shell, once the prey item has been encountered by the crab, was recorded (= breaking time). As feeding almost invariably ensued after the first successful crack in the shell, breaking time provided a more precise indicator of feeding efficiency than the more commonly used parameter of 'handling time', i.e. breaking time plus eating time. Between 15 and 20 mussels were presented individually to each crab, at approximately hourly intervals.

The second set of foraging experiments was carried out by providing individual crabs with mussels of 4 selected size categorles $(12.0-13.9 \mathrm{~mm}, 14.0-15.9 \mathrm{~mm}$, $17.0-18.9 \mathrm{~mm}$ and $19.0-20.9 \mathrm{~mm}$ shell length respectively) and the breaking times recorded. At least 10 mussels were presented to each crab and the average breaking time calculated. All mussels used were collected from the same site and tidal level in order to minimize any habitat-induced variations in shell thickness. Crabs $(\mathrm{n}=10)$ used in these experiments measured 43.5 to $68.8 \mathrm{~mm} \mathrm{CW}$ with master chelae ranging from 10 to $25 \mathrm{~mm}$ in height.

The importance of hard-bodied prey in the natural diet of Carcinus maenas was assessed by examining the gut contents of 115 individuals collected during February-March 1989 from beneath Bangor Pier in the Menai Strait, where well established barnacle and mussel beds are also present. The foreguts of freshly collected crabs were cut open and the contents flushed out. Each food item was identified using a stereomicroscope and expressed in terms of the number of stomachs in which it occurred (= \% occurrence).

Use of chelae in reproduction. The relationship between cheliped size and reproductive success was evaluated by comparing the distributions of chelal height amongst shore-collected male Carcinus maenas within mating pairs with those obtained for the male crab population of similar size collected from the same locality. A high percentage of chelae above the male population average would be expected from the mating males if cheliped size is indeed important in mate competition. Mating pairs were collected throughout the reproductive season of 1989 .

Agonistic interactions. Models of Carcinus maenas with various chelal height to carapace width ratios were 
constructed using fresh, intact moults collected from the shore. Chelipeds of different sizes were then removed and reattached by means of quick setting cement to crabs of either $42 \mathrm{~mm}$ or $52 \mathrm{~mm} \mathrm{CW}$. Five models were prepared for each series in such a way that the size of the master chelae ranged from approximately $0.7 \times$ to $1.5 \times$ the average population values for male crabs of that particular carapace width. All models were set in the high intensity lateral merus display posture (Wright 1968) in order to elicit a response from the subject.

These models were then mounted on glass rods and presented, in random order, to male Carcinus maenas of different carapace widths. The subjects $(n \geq 10)$ to which the models were presented were kept in small $(30 \times 20$ $\times 15 \mathrm{~cm}$ ) shaded aquaria for at least $24 \mathrm{~h}$ before the start of the experiment, and models were presented at $\geq 1 \mathrm{~h}$ intervals in a random sequence. Models were introduced into the opposite end of the tank and moved slowly and steadily towards the subject. The responses of the subjects when presented with such models were categorised as follows: (a) attack; (b) high intensity lateral merus display (HILM); (c) medium intensity lateral merus display (MILM); (d) low intensity lateral merus display (LILM); (e) retreat/submission; and (f) no response. Crabs exhibiting these responses have characteristic postures involving different degrees of cheliped spread and body profile (Wright 1968, Hazlett 1970). Models were presented to subjects of the same carapace width or to those belonging to the other size group. One or 2 trials for each subject were run with each model and the response exhibited by the subjects recorded. Consistency in the response patterns of the subjects when presented with different models was examined by a Chi-square test of independence.

Maintenance cost. The basal metabolic ratc of resting (inactive) crabs was estimated from measurements of oxygen consumption. These experiments were confined to Liocarcinus holsatus in view of the much smaller mature body size of this crab compared to Carcinus maenas. All experimental crabs $(\mathrm{n}=32)$ were starved for $2 \mathrm{~d}$ before any measurements were made in order to avoid any disturbance to the metabolic rate which may result from the food ingested prior to the experiment (Wallace 1973). The chelipeds of 8 individuals were removed and the crabs allowed to recover for 1 mo before their metabolic rates were similarly measured. Oxygen consumption rate was determined by monitoring the changes in dissolved oxygen concentration in a sealed respirometer of $750 \mathrm{ml}$ capacity. The respirometer was filled with oxygen-saturated, fully saline (33 to $34 \%$ ) filtered seawater and maintained at 15 to $16^{\circ} \mathrm{C}$. The water was stirred by a submersible magnetic stirrer and the dissolved oxygen partial pressure monitored by a Radiometer oxygen-pH analyser. All crabs were allowed to settle in the respirometer for at least $45 \mathrm{~min}$ before measurements commenced and the change in oxygen partial pressure was then monitored over a period of $\geq 45 \mathrm{~min}$. Preliminary measurements showed that oxygen uptake by the crabs was independent of oxygen concentration down to approximately $20 \%$ saturation. The total dry weight of the experimental crabs varied from 2 to $4 \mathrm{~g}$.

\section{RESULTS}

\section{Cheliped morphometrics}

Both Carcinus maenas and Liocarcinus hosaltus are heterochelous, with a predominance of righthandedness in both sexes (Table 1). Sexual dimorphism in chelal size, but not structure (occlusive geometry), is also evident. In sexually mature individuals both chelal height and mechanical advantage at the dactylus tip are significantly greater amongst male crabs than amongst females of comparable carapace width (Table 1 ). The higher mechanical advantage $(a / b)$ of male crabs is due to the greater distance (a) between the point of attachment of the flexor (= closer) apodeme

Table 1. Carcinus maenas, Liocarcinus holsatus. Summary of the morphometric data for chelipeds of 2 crabs. MCH: master chela height; CW: carapace width; MASMA: master chela mechanical advantage; CUTMA; cutter chela mechanical advantage; CHWT: total cheliped weight; BW: body weight; \%RH: \% right-handed; \%LH: \% left-handed. All values are mean \pm 1 SD. Handedness data were collected from $L$. holsatus $(n=112)>26.1 \mathrm{~mm} \mathrm{CW}$ and $C$. maenas $(\mathrm{n}=412)>12.3 \mathrm{~mm} C W$. All other data were obtained from sexually mature individuals. The handedness data do not always add up to $100 \%$ because some individuals showed no distinguishable differences in size between the left and right chelipeds

\begin{tabular}{|lcccc|}
\hline & \multicolumn{2}{c}{ C. maenas } & & L. holsatus \\
& Males & Females & Males & Females \\
\hline MCH/CW & $0.285 \pm 0.032$ & $0.225 \pm 0.024$ & $0.239 \pm 0.011$ & $0.220 \pm 0.009$ \\
MASMA & $0.327 \pm 0.044$ & $0.282 \pm 0.027$ & $0.247 \pm 0.027$ & $0.222 \pm 0.029$ \\
CUTMA & $0.264 \pm 0.023$ & $0.251 \pm 0.025$ & $0.224 \pm 0.027$ & $0.215 \pm 0.025$ \\
CHWT/BW & $0.184 \pm 0.023$ & $0.119 \pm 0.020$ & $0.194 \pm 0.020$ & $0.144 \pm 0.011$ \\
\%RH & 75.6 & 62.5 & 87.0 & 96.3 \\
\%LH & 18.5 & 10.9 & 0 & 0 \\
\end{tabular}


(c) and the dactylar pivot (p) rather than to a shorter dactylus (b) (Fig. 1); consequently this corresponds to the greater chelal height reported for male crabs. The chelipeds in both $C$. maenas and $L$. holsatus account for about $20 \%$ of total body fresh weight in male crabs but $<15 \%$ in females. Values for the ratio of master chelal height to carapace width for females were similar $(0.22$ to 0.23$)$ in both species, whereas the relative size of male $C$. maenas master chelae (0.29) was much larger than that of $L$. holsatus $(0.24)$. Mechanical advantage at the dactylus tip of $C$. maenas was again higher than that of $L$. holsatus. C. maenas, especially the males, are thus able to generate much greater forces than either $L$. holsatus or female conspecifics of comparable size. Speed of chela closure, however, is inversely related to mechanical advantage. The difference in mechanical advantage (and speed) between L. holsatus and C. maenas probably reflects differences in foraging pattern. L. holsatus, having a much smaller mechanical advantage, is better adapted to capturing faster moving soft-bodied prey, e.g. epibenthic polychaetes, whereas $C$. maenas is better suited to handling larger and harder prey.

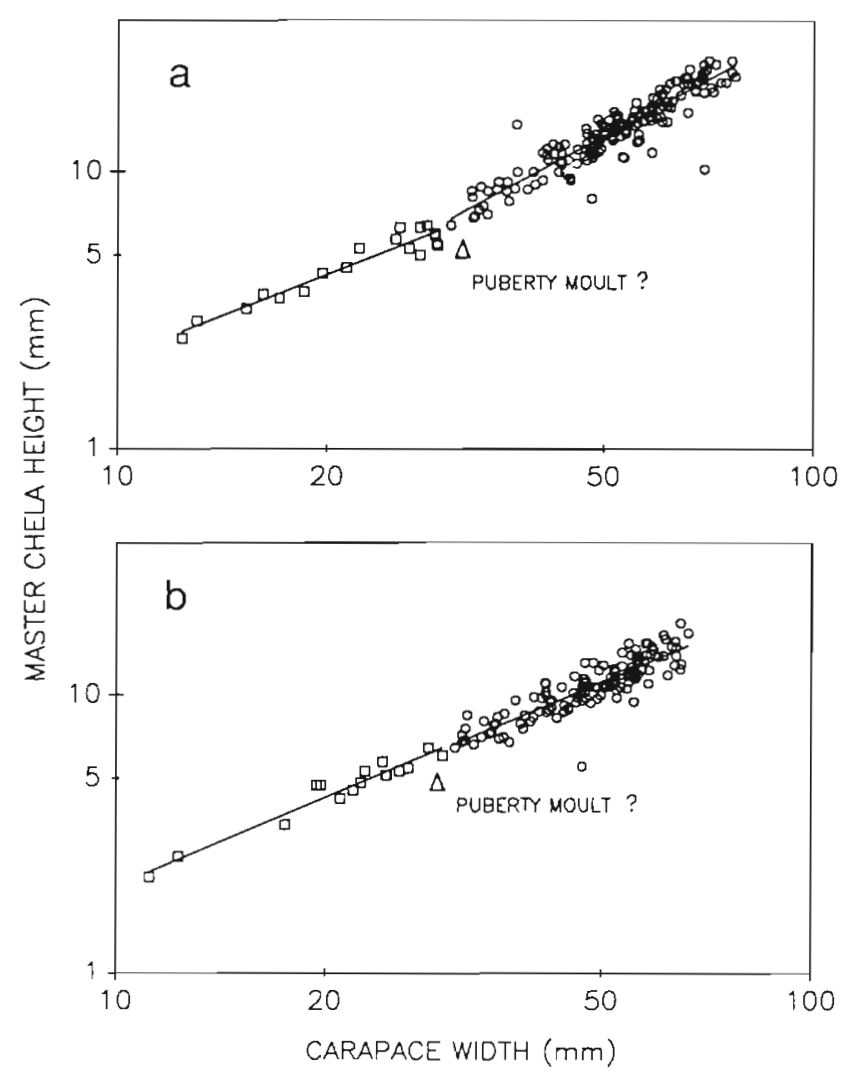

Fig. 2. Carcinus maenas. Allometric relationships between master chelal height and carapace width in (a) male and (b) female crabs. Note the conspicuous change in slope amongst male crabs $<30$ and $>30 \mathrm{~mm}$ carapace width

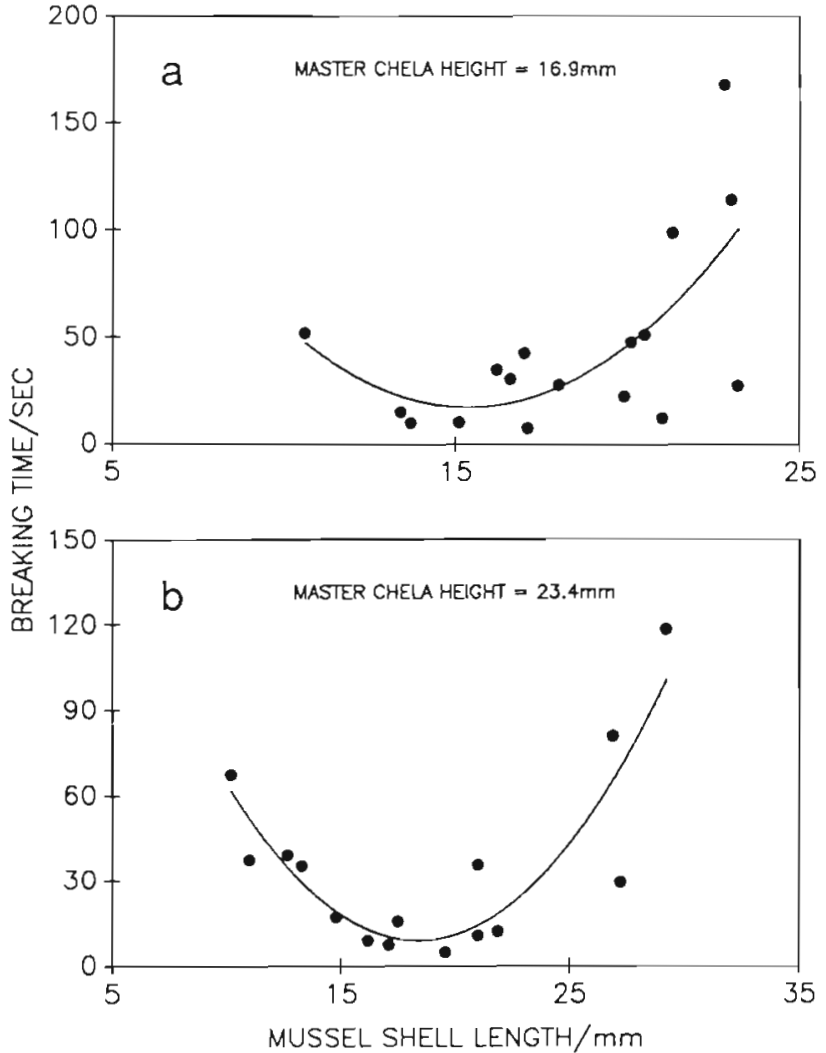

Fig. 3. Carcinus maenas, Mytilus edulis. Relationship between breaking time and mussel shell length amongst crabs with master chelae height of (a) $16.9 \mathrm{~mm}$ and (b) $23.4 \mathrm{~mm}$.

Curves were computed using non-linear regression models

The fact that chelal size may have an associated sexual function is strongly suggested by the change of slope (at about $30 \mathrm{~mm} \mathrm{CW}$ ) in the regression between chelal height and carapace width in male Carcinus maenas (Fig. 2a). Regression lines for sub-populations greater or smaller than $30 \mathrm{~mm} \mathrm{CW}$ have significantly different slopes for male crabs (slope for individuals $>30 \mathrm{~mm} \mathrm{CW}=1.287$, for $<30 \mathrm{~mm} \mathrm{CW}=1.082$; $p<0.005)$. No significant change is evident in female crabs (slope for individuals $>30 \mathrm{~mm} \mathrm{CW}=1.055$, for individuals $<30 \mathrm{~mm} \mathrm{CW}=1.049 ; \mathrm{p}>0.05$ ) (Fig. 2b).

\section{Prey handling}

The time required by Carcinus maenas to break open Mytilus edulis generally followed U-shaped profiles when plotted against mussel shell length (Fig. 3a, b). While prolonged handling is required to break large mussels, breaking time also increased when mussels become too small for the chelae to handle them efficiently. When prey length at minimum breaking time is plotted against chelal height, a 


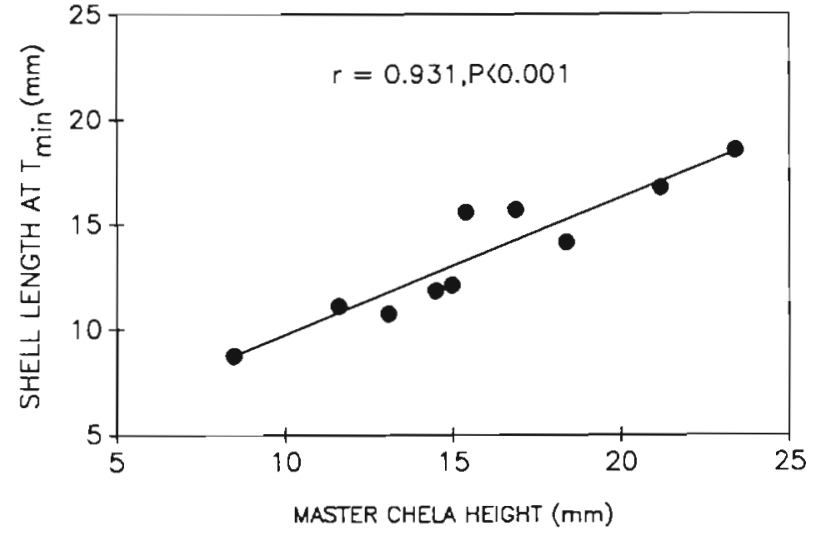

Fig. 4. Carcinus maenas, Mytilus edulis. Relationship between mussel shell length at minimum breaking time $\left(T_{\min }\right)$ and master chela height

straight line is obtained $\left(T_{\min }=3.244+0.625\right.$ (master chelal height); $r^{2}=0.867, p<0.001$; Fig. 4).

The fact that Carcinus maenas with bigger master chelal height can exploit much larger prey items is also demonstrated by the change in the relationship between mean breaking time and chelal height for mussels of any given shell length (Fig. 5). Mean breaking time increased steeply when progressively larger mussels were handled by crabs with small master chelae, while breaking times exhibited relatively little variation amongst crabs with larger master chelae.

Gut content analyses of crabs collected during February 1989 suggested that Carcinus maenas probably does not rely exclusively on hard-bodied prey in nature. Of the 115 C. maenas collected from a site with extensive mussel and barnacle populations, 59 contained identifiable food items and of these only $16(27.1 \%)$ contained some fragments of crustacean or molluscan origin. The most common food items were fucoid and filamentous algae which had a frequency of occurrence of $64.4 \%$ of all food items found (Fig. 6); $28(47.5 \%)$ of the filled stomachs contained nothing but algae.

\section{Reproductive use}

Over $90 \%$ of the males in the 35 mating pairs of Carcinus maenas collected intertidally in the Menai Strait had above average sized master and cutter
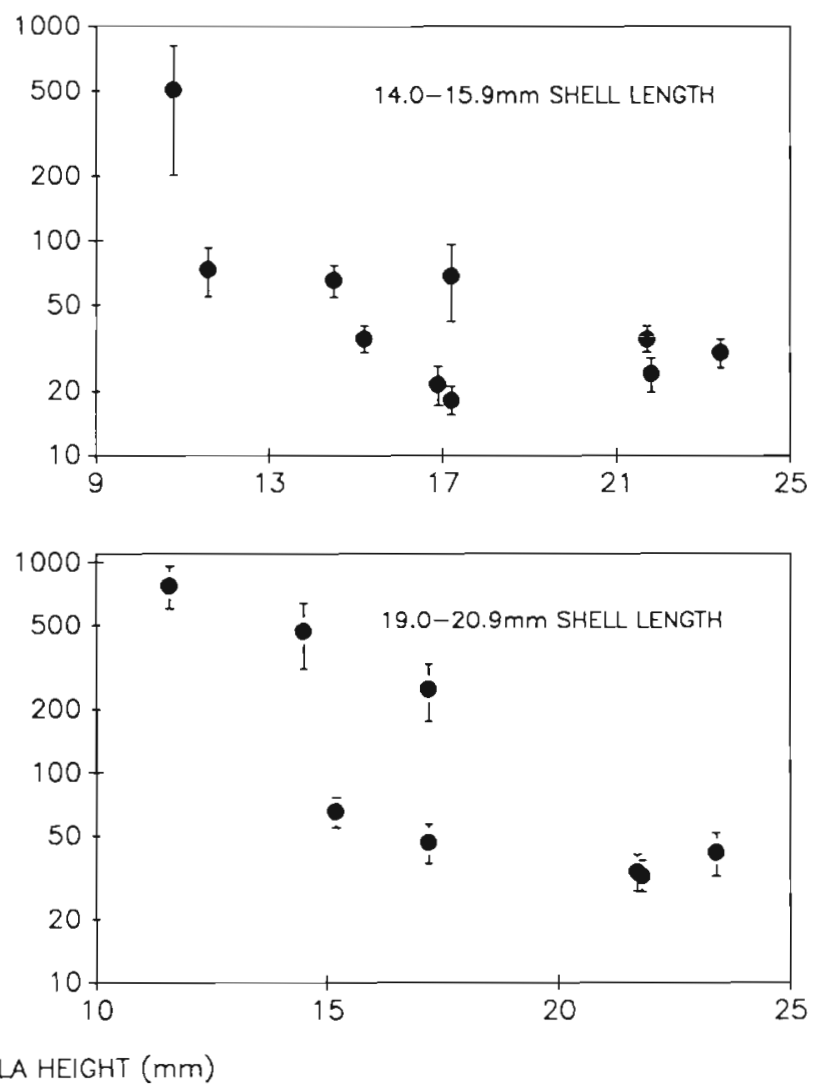

Fig. 5. Carcinus maenas, Mytilus edulis. Variations in breaking time (mean \pm 1 SD) of 4 selected size categories of mussels when offered to crabs with master chelae of different size. Only male crabs were used in these experiments 


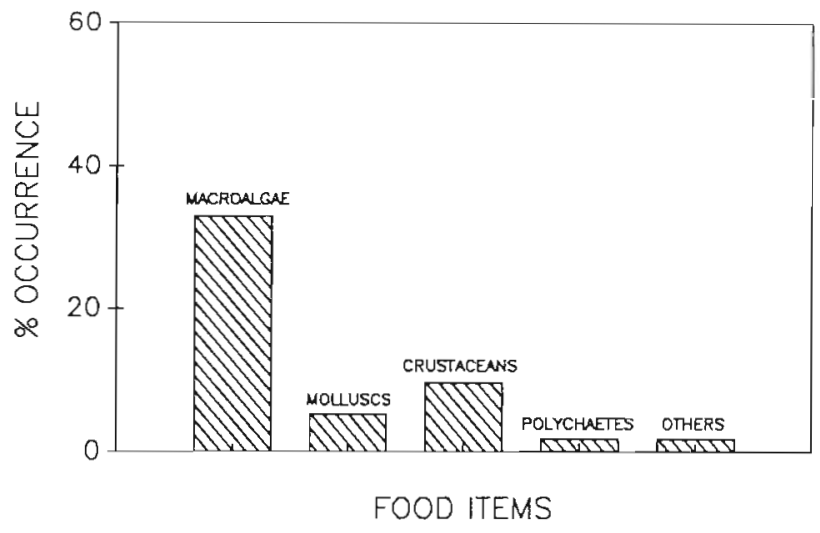

Fig. 6. Carcinus maenas. Frequency occurrences of various food items in the foregut of crabs collected from the Menai Strait during February $1989(\mathrm{n}=59)$

chelae when compared with values predicted by the regression equations for the total male population (Fig. 7). Analysis of covariance revealed that over the same size range significant differences in the size of both chelae exist between the mating male population and the total male population (for master chelae $F_{1.56}=9.758, p<0.005$; for cutter chelae $F_{1,56}=6.585$, $p<0.025$ ). No males less than $60 \mathrm{~mm} \mathrm{CW}$ were found in the mating pairs.

\section{Agonistic interactions}

Response patterns exhibited by male Carcinus maenas to the presence of a potential conspecific competitor were strongly influenced by the size of their chelipeds (both chelal height and meral spread) relative to those of the model crabs; carapace width, on the other hand, was less important in determining the out. come of agonistic encounters (Fig. 8). These response patterns were significantly dependent on the ratio of the master chelal heights of the models and the subjects ( $\mathrm{df}=28, \mathrm{p} \ll 0.05$ for all 4 sets; Chi-square test). Subject response typically switched from a predominance of highly aggressive display patterns (attack, lateral merus displays at various intensities) to retreat or submission when the master chelal height (and meral spread) of the model exceeded that of the subject, but was generally independent of the carapace width of the model relative to that of the subject's. This is particularly well illustrated by the change from a highly aggressive response to one of submission when $52 \mathrm{~mm} \mathrm{CW}$ crabs were presented with a $42 \mathrm{~mm}$ model having a master chela equivalent to $1.13 \times$ that of the subject (Fig. $8 \mathrm{~b}$ ). Subjects of $42 \mathrm{~mm} \mathrm{CW}$ also responded aggressively toward a $52 \mathrm{~mm}$ model which had a smaller master chela than themselves (Fig 8d).

\section{Maintenance $\cos t$}

The average oxygen consumption rate for inactive Liocarcinus holsatus was $0.281 \pm 0.103 \mathrm{ml} \mathrm{O}_{2} \mathrm{~g}^{-1} \mathrm{~h}^{-1}$ The rate was independent of crab size, $(\mathrm{r}=0.196$, $p>0.1)$ for the regression between specific oxygen consumption rate and total body dry weight. The oxygen uptake rate could be predicted from dry weight alone, irrespective of the presence or absence of chelipeds or the proportion of total body dry weight that can be attributed to the cheliped (Fig. 9).

\section{DISCUSSION}

Notwithstanding the strong bias towards foraging needs in explaining the size and structure of crab chelae, size determination for such multifunctional structures is probably determined by the interplay of several selective forces. Fitness implications of all the pertinent attributes of such multifunctional structures should, therefore, be considered in order to fully understand the evolution of their size and structure.
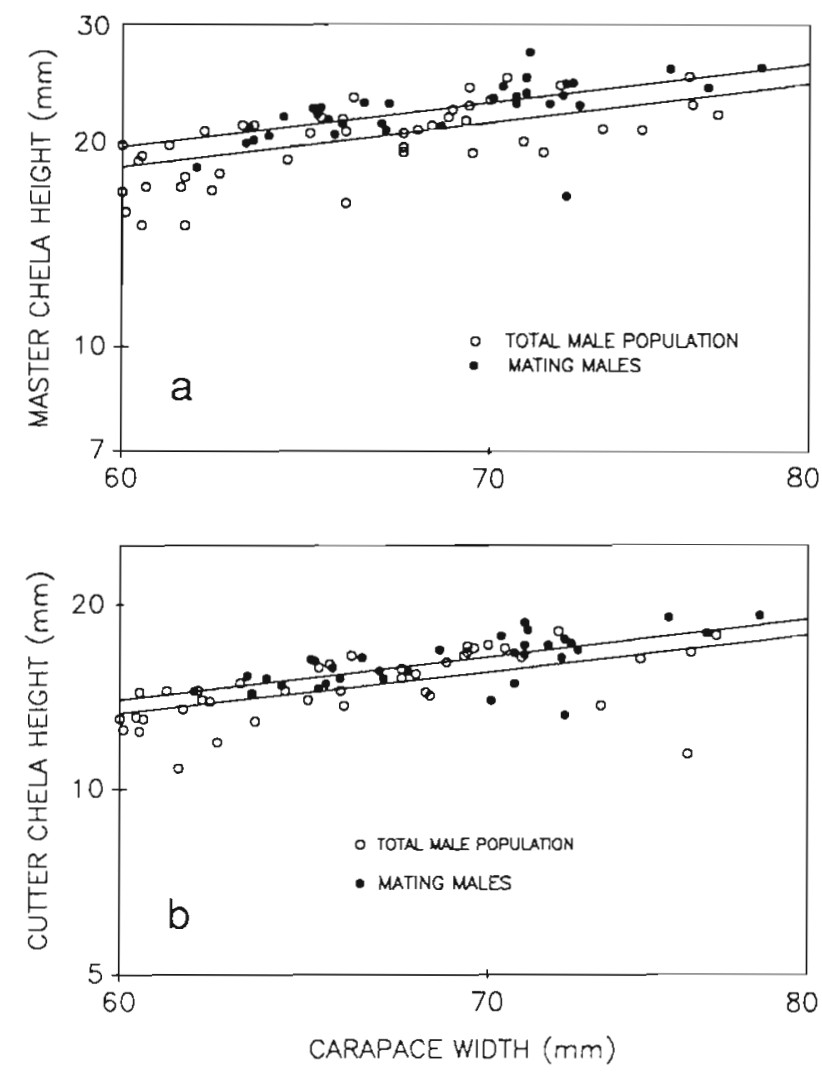

Fig. 7 Carcinus maenas. Relationships between chelal size and carapace width for mating male crabs compared with those for the total male population. (a) Master chelae; (b) cutter chelae 


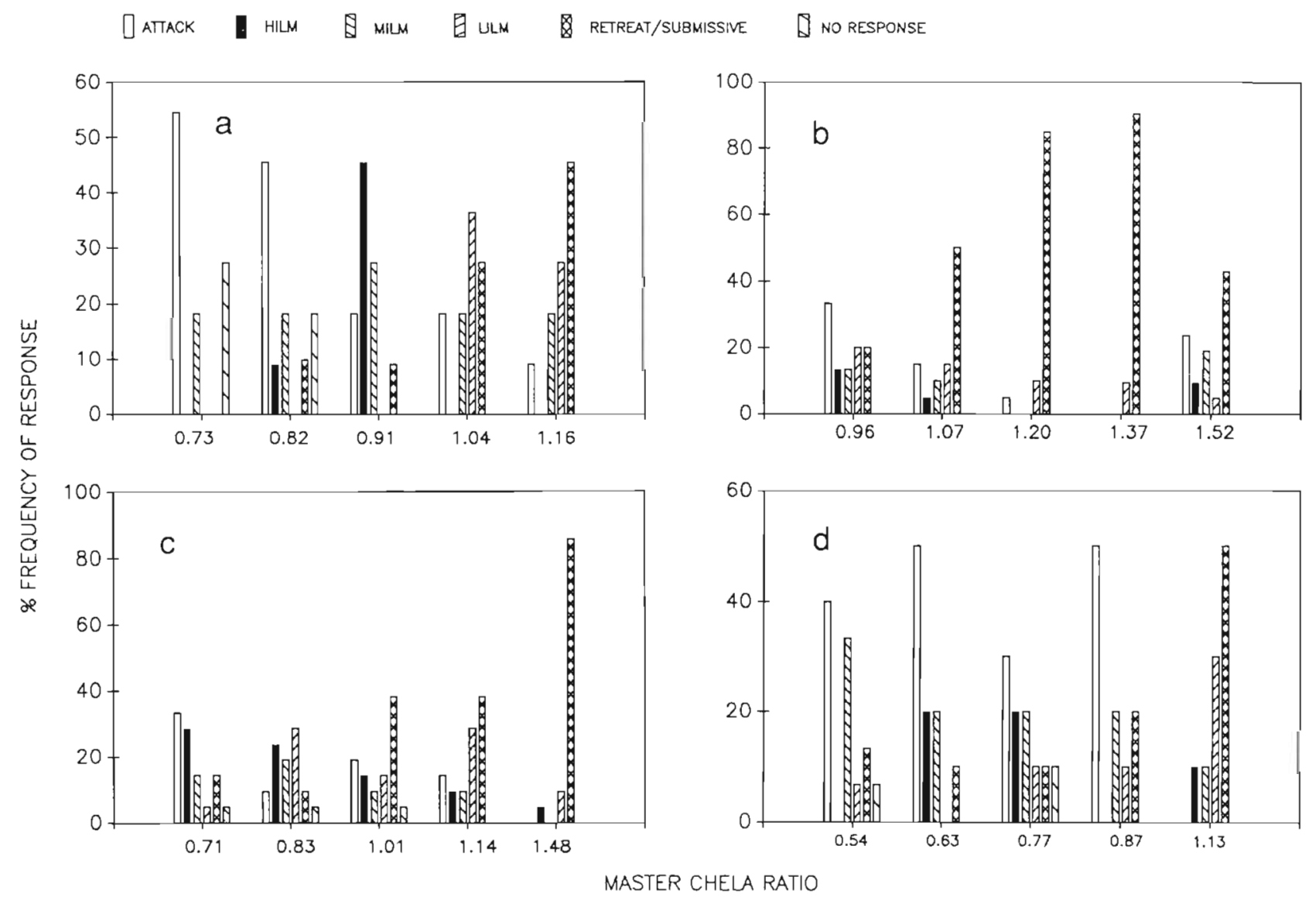

Fig. 8. Carcinus maenas. Responses of male crabs when presented with models of master chela of different size. (a) $\mathrm{Model} C \mathrm{CW}=$ subject $\mathrm{CW}=42 \mathrm{~mm}$; (b) model $\mathrm{CW}=42 \mathrm{~mm}$, subject $\mathrm{CW}=52 \mathrm{~mm}$; (c) model $\mathrm{CW}=$ subject $\mathrm{CW}=52 \mathrm{~mm}$; (d) model CW $=52 \mathrm{~mm}$; subject $C W=42 \mathrm{~mm}$. Note the change in response pattern when the master chela ratio (ratio of the master chela height of the model to that predicted by the population regression for the subject CW) exceeds unity. HILM: high intensity lateral mercus display; MILM: medium intensity; LILM: low intensity

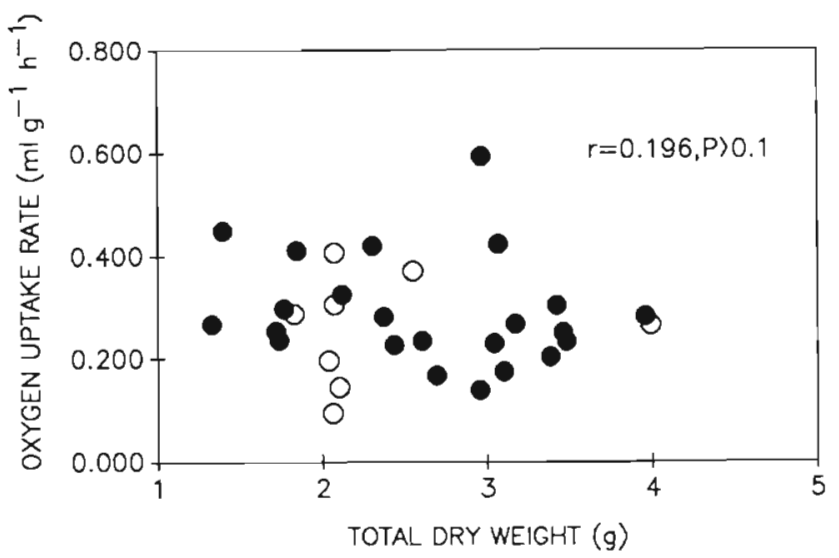

Fig. 9. Liocarcinus holsatus. Relationship between oxygen consumption rate and total body dry weight at $15^{\circ} \mathrm{C}$; $(0)$ normal individuals; $(0)$ individuals lacking chelipeds. No correlation existed between the rate of oxygen uptake and total body dry weight
While chelal structure may strongly reflect the foraging habits of predatory crabs (Elner 1978, Brown et al. 1979), results of the present study suggest that optimization in foraging and diet can only be one of the forces shaping cheliped size.

Results of the crushing experiments using the mussel Mytilus edulis as prey suggest that crabs possessing stronger and bigger chelae are able to exploit a wider size range of hard-bodied prey. Such crabs are probably also able to exploit a wider spectrum of prey species. Whilst there have been many studies on diet optimization of crabs feeding on a single prey species using laboratory measurements of 'profitability' (energy gained per unit handling time) (e.g. Elner 1980, Cunningham \& Hughes 1984), fewer data are available on diet optimization in crabs in their natural habitat. Ropes (1968), Elner (1981) and Abbas (1985) reported upon the natural diet of Carcinus maenas; all suggested that molluscs (e.g. Mytilus, Mya) and crustaceans (e.g. Balanus) were important prey items. 
Nevertheless, these studies revealed the diversity of, and seasonal variability in, food items consumed by C. maenas, and indicated that hard-bodied prey were often only part of the natural diet. The present study detected no predominance of hard-bodied prey but a prevalence of algae in the diet of C. maenas, thus broadly agreeing with the results of an earlier study by Elner (1977) at the same study site. Data on other portunid crabs also suggest only a moderate degree of diet specialization on hard-bodied prey (e.g. Paul 1981, Williams 1982, Davidson \& Marsden 1987). Most crabs are probably opportunistic foragers and it is questionable how optimal a diet consisting only of hard-bodied prey could be in nature. It perhaps also then becomes questionable whether the cheliped, which in C. maenas can account for $>30 \%$ of the total body weight, evolved only in response to the selective pressure for obtaining an optimal diet consisting primarily of hard-bodied prey.

Measurements of the 'maintenance cost' for the chelipeds of Liocarcinus holsatus suggest that these structures impose no higher maintenance cost than other organs in the body, as oxygen uptake rate could be predicted from dry tissue weight alone. The average oxygen consumption rate of $0.281 \pm 0.103 \mathrm{ml}$ $\mathrm{O}_{2} \mathrm{~g}^{-1} \mathrm{~h}^{-1}$ in inactive L. holsatus is comparable to the data available for Carcinus maenas of similar size (Newell et al. 1972, Wallace 1972). Since the chelipeds typically make up ca $20 \%$ of the total body weight in both crabs, approximately the same proportion of energy is presumably spent on their maintenance. In L. holsatus, however, large chelipeds can cause disproportionately higher metabolic rates during periods of active swimming (authors' unpubl. data); this may explain the negatively allometric relationship between cheliped size and carapace width reported for some swimming crabs (Davidson \& Marsden 1987).

Stein (1976) provided experimental data on the importance of the cheliped in mate competition in crayfish and hypothesized that sexual selection is probably the major driving force in the evolution of large chelae. The importance of the cheliped in other activities related to individual fitness, however, was also reported by Stein (1976) and demonstrated by this study. Wright (1968) reviewed visual display in several brachyrhynchan crabs and concluded that cheliped movements constituted the major component in the expression of aggressiveness. Hazlett $(1969,1972)$ provided further data on the importance of the cheliped in intraspecific encounters in both anomuran and brachyuran crabs.

The importance of the cheliped in the acquisition of a mate/aggression is supported by the findings of the present investigation. Mating in portunids typically occurs when the female body is soft; during this period, which can last for several days before and after moult- ing (Hartnoll 1969), the female is protected by the male. This prolonged courtship behaviour in species like Carcinus maenas which can occur at exceedingly high densities in the Menai Strait (Dare \& Edwards 1981) may evoke intense competition among male crabs for mates. No tendency for females to select males was observed in the laboratory; rather, the formation of mating pairs is achieved following male fights, and aggression among male crabs typically increases during the mating season (authors' unpubl. obs.). Such fighting behaviour is effectively an intrasexual selection among the males, as only males strong enough to defend the female during the period when she is vulnerable and requires protection can reproduce successfully. It is logical, therefore, to expect that the chelae, being the major structures involved in the expression of aggressive behaviour, would be significantly larger amongst the successful males in mating pairs, in addition to a generally larger size in males than females. Zucker (1984) also reported that the average size of the master chela in courting male fiddler crabs was significantly greater amongst crabs at high population densities.

Further support for the view that the evolution of massive chelipeds in crabs is driven by sexual selection is provided by the growth patterns of the chelipeds themselves. Hartnoll $(1974,1978,1982)$ documented significant changes in the allometry of various parts of the body, including the chelae, of crabs at sexual maturity. Such changes are also clearly evident in male Carcinus maenas (Fig. 2a) thus suggesting a probable sexual function. Apart from sexual dimorphism, seasonal polymorphisms have also been reported in some decapods (Stein 1976, Hartnoll 1982), with males having bigger chelae during periods of reproductive activity. Female crabs by contrast probably invest more energy in gamete production than the males, since clutch sizes can be in the order of $10^{6}$ eggs (Warner 1977). The distinctly different roles of the 2 sexes during courtship, with much inter-male conflict in which the chelipeds are the main organs of aggression, suggest that sexual selection is a major driving force controlling sexual dimorphism in cheliped size. The maintenance of such a costly structure during nonreproductive periods in male crabs further suggests that the size of the female chelae may be closer to the energetic survival optimum. Survival optima for both sexes are often very similar when differences in reproductive behaviour are discounted (see for example Sandell 1989), though sexual selective pressures may act in 'positive feedback' modes thus resulting in dramatic developments of fitness-related structures (Dawkins 1986). One obvious example of this is the massive master chela in fiddler crabs which serves no feeding function. 
Results of the experiments using models of various chelal size to body size ratios confirm the importance of the chelipeds in agonistic encounters, not only in mate competition, but probably also in other interactions such as competition for food and shelter. Sinclair (1977) and O'Neill \& Cobb (1979) documented the importance of several morphometric parameters in agonistic encounters in the stone crab Menippe mercenaria (Say) and in shelter competition in 3 species of lobsters respectively. In both studies dominance was influenced by greater carapace width, sex, hard exoskeleton and greater chelal size but these authors did not assign more significance to the size of the chelipeds over the other attributes. However, greater chela size, as their data for the 4 species studied showed, was strongly correlated with all the other morphometric attributes (Sinclair 1977, O'Neill \& Cobb 1979). Glass \& Huntingford (1988) studied the agonistic interactions between Liocarcinus depurator (L.) individuals and concluded that the relative size of individual crabs was important in predicting the outcome of fights. These authors also demonstrated that smaller crabs could win in fights involving crabs of very similar size (carapace width). Such deviations may be explained if the natural variability in the chelal size to carapace width ratio (e.g. due to previous loss and the subsequent regeneration of a smaller claw), is taken into consideration. The results of our model experiments strongly suggest that cheliped size rather than body size (carapace width) is the basic indicator of dominance in Carcinus maenas and probably also in other crabs.

Acknowledgements. This research was conducted during the tenure of a Croucher Foundation Postdoctoral Fellowship awarded to S.Y.L. S. Y. Lee thanks Drs Graham Walker, Chris Richardson, John Davenport, Prof. E. Naylor and Prof. R. N. Hughes (all of University of Wales Bangor) for their hospitality and valuable discussions. Drs D. Reid and P. Abello allowed us to measure some of their specimens, for which we are grateful. Gwyn Jones, Bob Roberts and mates of RV 'Prince Madog' and RV 'Lewis Morris' helped in collecting crabs.

\section{LITERATURE CITED}

Abbas, S. A. M. (1985). Predation of infaunal bivalves by Carcinus maenas in the Burry Inlet, South Wales. Ph.D. thesis, University of Wales, Swansea

Abby-Kalio, N. J., Warner, G. F. (1989). Heterochely and handedness in the shore crab Carcinus maenas (L.) (Crustacea: Brachyura). Zool. J. Linn. Soc. 96: 19-26

Abele, L. G., Heck, K. L. Jr, Simberlaff, D. S., Vermeij, G. J. (1981). Biogeography of crab claw size: assumptions and a null hypothesis. Syst. Zool. 30: 406-424

Alexander, R. MCN. (1983). Animal mechanics, 2nd edn. Blackwell Scientific Publications, Oxford

ap Rheinallt, T. (1986). Size selection by the crab Liocarcinus puber feeding on mussels Mytilus edulis and on shore crabs Carcinus maenas: the importance of mechanical factors. Mar. Ecol. Prog. Ser. 29: 45-53
Blundon, J. A., Kennedy, V. S. (1982). Mechanical and behavioural aspects of blue crab. Callinectes sapidus (Rathbun), predation on Chesapeake Bay bivalves. J. exp. mar. Biol. Ecol. 65: 47-65

Brown, S. C., Cassuto, S. R., Loos, R. W. (1979). Biomechanics of chelipeds in some decapod crustaceans. J. Zool. Lond. 188: $143-159$

Cunningham, P. N., Hughes, R. N. (1984). Learning of predatory skills by shorecrabs Carcinus maenas feeding on mussels and dogwhelks. Mar. Ecol. Prog. Ser 16: $21-26$

Dare, P. J., Edwards, D. B. (1981). Underwater television observations on the intertidal movements of shore crabs, Carcinus maenas, across a mudflat. J. mar. biol. Ass. U.K. 61: $107-116$

Davidson, R. J. (1986). Mussel selection by the paddle crab Ovalipes catharus (White), evidence of flexible foraging behaviour. J. exp. mar. Biol. Ecol. 102: 281-299

Davidson, R. J., Marsden, I. D. (1987). Size relationships and relative growth of the New Zealand swimming crab Ovalipes catharus (White, 1843). J. Crust. Biol. 7: 308-317

Dawkins, R. (1986). The blind watchmaker. Penguin Books, London

Ebling, F. J., Kitching, J. A., Muntz, L., Taylor, C. M. (1964). The ecology of Lough Ine. XIII. Experimental observations of the destruction of Mytilus edulis and Nucella lapillus by crabs. J. Anim. Ecol. 33: 73-82

Elner, R. W. (1977). The predatory behaviour of Carcinus maenas (L.). Ph.D. thesis, University College of North Wales, Bangor

Elner, R. W. (1978). The mechanics of predation by the shore crab Carcinus maenas (L.) on the edible mussel, Mytilus edulis L. Oecologia 36: 333-344

Elner, R. W. (1980). The influence of temperature, sex and chela size in the foraging strategy of the shore crab, Carcinus maenas (L.). Mar. Behav. Physiol. 7: 15-24

Elner, R. W. (1981). Diet of green crab Carcinus maenas (L.) from Port Hebert, southwestern Nova Scotia. J. Shellfish Res. 1: $89-94$

Elner, R. W., Campbell, A. (1981). Force, function and mechanical advantage in the chelae of the American lobster Homarus americanus (Decapoda: Crustacea). J. Zool., Lond. 193: 269-286

Glass, C. W. Huntingford, F. A. (1988). Initiation and resolution of fights between swimming crabs (Liocarcinus depurator). Ethology 77: 237-249

Hamilton, P. V., Nishimoto, R. T., Halusky, J G. (1976). Cheliped laterality in Callinectes sapidus (Crustacea: Portunidae). Biol. Bull. 150: 393-401

Hartnoll, R. G. (1969). Mating in the Brachyura. Crustaceana 16: $161-181$

Hartnoll, R. G. (1974). Variation in growth pattern between some secondary sexual characters in crabs (Decapoda: Brachyura). Crustaceana 27: 131-136

Hartnoll, R. G. (1978). The determination of relative growth in Crustacea. Crustaceana 34: 281-293

Hartnoll, R. G. (1982). Growth. In: Abele, L. G. (ed.) The biology of Crustacea. 2: Embryology, morphology, and genetics. Academic Press, New York, p. 111-196

Hazlett, B. A. (1969). Further investigations of the cheliped presentation display by Pagurus bernhardus (Decapoda, Anomura). Crustaceana 17: 31-34

Hazlett, B. A. (1970). Interspecific fighting in three species of Brachyuran crabs from Hawaii. Crustaceana 20: 308-314

Hazlett, B. A. (1972). Responses to agonistic postures by the spider crab Microphrys bicornutus. Mar. Behav. Physiol. 1: $85-92$ 
Hughes, R. N. (1989). Foraging behaviour of a tropical crab: Ozius verreauxii. Proc. R. Soc. Lond., Ser. B, 237. 201-212

Jensen, K. T., Jensen, J. N. (1985). The importance of some epibenthic predators on the density of juvenile benthic macrofauna in the Danish Wadden Sea. J. exp. Mar. Biol Ecol. 89: 157-174

Jubb, C. A., Hughes, R. N., ap Rheinallt, T. (1983). Behavioural mechanisms of size-selection by crabs, Carcinus maenas (L.) feeding on mussels, Mytilus edulis L. J. exp. mar. Biol. Ecol. 66: 81-87

Lawton, P., Elner, R. W. (1985). Feeding in relation to morphometrics within the genus Cancer evolutionary and ecological considerations. In: Proceedings of symposium on Dungeness crab biology and management. Alaska Sea Grant Report 85-3, p. 357-379

Newell, R. C., Ahsanullah, M., Pye, V I. (1972). Aerial and aquatic respiration in the shore crab Carcinus maenas (L.) Comp. Biochem. Physiol. 43A: 239-252

O'Neill, D. J., Cobb, J. S. (1979). Some factors influencing the outcome of shelter competition in lobster (Homarus americanus). Mar. Behav. Physiol. 6: 33-45

Paul, R. K. G. (1981). Natural diet, feeding and predatory activity of the crabs Callinectes arcuatus and $C$. toxotes (Decapoda,Brachyura, Portunidae). Mar. Ecol. Prog. Ser. 6 : 91-99

Rangeley, R. W. Thomas, M. L. H. (1987). Predatory behaviour of juvenile shore crab Carcinus maenas (L.) J. exp. mar. Biol. Ecol. 108: 191-197

Ropes, J. W. (1968). The feeding habits of the green crab, Carcinus maenas (L.). Fish. Bull. U.S. 67: 183-203

Sanchez-Salazar, M. E., Griffiths, C. L., Seed, R. (1987). The interactive roles of predation and tidal elevation in structuring populations of the edible cockle, Cerastoderma edule. Estuar. coast. Shelf Sci. 25: 245-260

Sandell, M. (1989). Ecological energetics, optimal body size and sexual dimorphism: a model applied to the stoat. Mustela erminea L. Funct. Ecol. 3: 315-324

Seed, R. (1982). Predation of the ribbed mussel Geukensia demissa by the blue crab Callinectes sapidus. Neth. J. Sea Res. 16: 163-172

Seed, R. (1990a). Morphology, occlusive geometry and mechanical advantage in the chelae of Thalamita danae Stimpson and $T$. crenata (Latreille) (Decapoda: Portunidae) from Hong Kong. In: Morton, B. (ed.) Proceedings of the Second International Biological Workshop: the marine flora and fauna of Hong Kong and Southern China,

This article was submitted to the editor
Hong Kong, 1986. Hong Kong University Press, Hong Kong, p. 1095-1111

Seed, R. (1990b). Predator-prey relationshups between the swimming crab Thalamita danae Stimpson (Decapoda: Portunidae) and the mussels Perna viridis (L.) and Brachidontes variabilis (Krauss). In: Morton, B. (ed.) Proceedings of the Second International Biological Workshop: the marine flora and fauna of Hong Kong and Southern China, Hong Kong, 1986. Hong Kong University Press, Hong Kong, p. 993-1013

Sinclair, M. E. (1977). Agonistic behaviour of the stone crab, Menippe mercenaria (Say). Anim. Behav. 25: 193-207

Stein, R. A. (1976). Sexual dimorphism in crayfish chelae: functional significance linked to reproductive activities. Can. J. Zool. 54: 220-227

Vermeij, G. J. (1976). Interoceanic differences in vulnerability of shelled prey to crab predation. Nature, Lond. 260: $135-136$

Vermeij, G. J. (1977). Patterns in crab claw size: the geography of crushing. Syst. Zool. 26:138-157

Wallace, J. C. (1972). Activity and metabolic rate in the shore crab. Carcinus maenas (L.). Comp. Biochem. Physiol. 41A: $523-533$

Wallace, J. C. (1973). Feeding, starvation and metabolic rate in the shore crab Carcinus maenas. Mar. Biol. 20: $277-281$

Warner, G. F. (1977). The biology of crabs. Elek Science, London

Warner, G. F., Chapman, D., Hawkey, N., Waring, D. G. (1982). Structure and function of the chelae and chela closer muscles of the shore crab Carcinus maenas (Crustacea: Brachyura). J. Zool., Lond. 196: 431-438

Warner, G. F., Jones, A. R. (1976) Leverage and muscle type in crab chelae (Crustacea: Brachyura). J. Zool., Lond. 180: $57-68$

Williams, M. J. (1982). Natural food and feeding in the commercial sand crab Portunus pelaqicus Linnaeus, 1766 (Crustacea: Decapoda: Portunidae) in Moreton Bay, Queensland. J. exp. mar. Biol. Ecol. 59: 165-176

Wright, H. O. (1968). Visual displays in brachyuran crabs: field and laboratory studies. Am. Zool. 8: 655-665

Zipser, E., Vermeij, G. J. (1978). Crushing behaviour of tropical and temperate crabs. J. exp. mar Biol. Ecol. 31 $155-174$

Zucker, N. (1984). Delayed courtship in the fiddler crab Uca musica terpsichores. Anim. Behav. 32: 735-742

Manuscript first received: November 5, 1991

Revised version accepted: May 19, 1992 